\title{
Religious Heritage and Values Perfecting Peacefulness Among the Contemporary Yorùbá
}

\author{
Akintayo Sunday Olayinka ${ }^{1}$ \\ ${ }^{1}$ Affiliation not available
}

November 4, 2022

\begin{abstract}
This paper presents the roles that religious heritage among the Yorùbá plays in sustaining their peacefulness. The Yorùbá use both formal and informal interactions to engage one another in discourses that enhance their togetherness but often faced with outside influences that can truncate their desired goals. This paper, therefore, places the Yorùbá by the established peaceful societies (PS) to see how they compare in their attitude to peacefulness and providing explanation to the Yorùbá's effort to keep the peace despite the outside influences on their society.
\end{abstract}

Please note: The bulk of this article is taken from chapter 8 of the author's doctoral dissertation with a few amendments to suit this journal.

Keywords: Christian-Muslim relations, peace studies, Africa - Yorùbá, religious - ethics, culture - values, Covid-19.

\section{Introduction}

At the inception of Christianity and Islam in Yorùbáland, each was allocated portions of land by local kings on which to build their worship centres and schools, while Christians in addition, built hospitals to look after the sick. On some occasions, thick forests were allocated to Christians, but in time such places developed to become habitable. A few examples of institutions transformed from these allocated lands are the Nigerian Baptist Theological Seminary, Ògbómoso, and the Bowen University Teaching Hospital (formerly known as the Baptist Medical Centre Ògbómoso) in Nigeria. Others are the Baptist College Iwo now the Bowen University Iwo and the Baptist Hospital Shaki. Muslims moved their schools [madrasati] often attached to the Mosques to establish primary and secondary school at different locations away from the Mosques site, with few examples in Ògbómoso, Ilorin, and Ibadan in Nigeria to mention but a few.

Unlike the examples mentioned above, religion has been found to be the cause of division and violence in many places. Nevertheless, religion has demonstrated the ability to present peace when utilised as advocacy for peace. How this contrast supports peacefulness among a thriving religious community is an area that could be explored further. Christianity and Islam among the Yorùbá often have events that bring them together be it at family level, social gathering, and workplaces. What are the reasons behind the Yorùbá's disposition toward one another and what contributions could that offer peace studies? This paper presents Yorùbá Christians and Muslims' capacity to maintain peacefulness, juxtaposed with the peaceful societies (PS) and some Senegalese examples. 


\section{Inter-Religious Discourses around Peacefulness}

There have been occasions of resentment among the Yorùbá due to how the indigenous religion [Indigenous Yorùbá African religion] - (IAR) was treated by the new religions (Islam and Christianity) and vice versa, but the three were ultimately able to form strong relationships with time. They did this by engaging in dialogue, (Chukwulozie, 1986; Akinade, 1996; Nigerian Dialogue, 1976) to understand one another better. For instance, the Orò Yorùbá festival forbids women from going outside during their festival. A clergyman, Rev'd. Solomon Aisa Ige (1890-1982), a recognized Baptist minister - longest serving minister of a Baptist Church for fifty-nine years (1917-1976) and a respected personality within the Ògbómso palace chieftains was influential in the dialogue to resolve this (Oludele, 2007). Ige led the Christians to demand freedom for their women to attend Sunday evening services in Ògbómso including during the Orò festival. The two groups worked out the negotiation peacefully as Orò began to go out late in the night in Ògbómso.

At a different location, a Christian contact in an interview in Sptrí town, Gábú, testifies that Maku, a Muslim respected cleric was friendly towards the Christian community in the town. Maku was welcoming despite a conflict between a Muslim group and the Christian community that lasted close to a decade in their town. The conflict within Spetrí was linked to the way in which religion was interpreted and taught among the militant group, not the widely acceptable norm of the Yorùbá Muslim community. The weird interpretations of religion are found to be incompatible with the culture an average Yorùbá person would want to promote be it Christians or Muslims. As a result, individual and group attitudes have to do with their upbringing and what they learn or consider acceptable through the agency of the religion, culture, or other avenues of direct or indirect learning. The learning that dominates in an individual or group takes pre-eminence in the community at large. For instance, Maku, the Muslim cleric suggests:

Christians and Muslims are not idolatrous; hence Christians are not kafir [unbelievers]. Only the idolaters are Kafir [whom Maku described as the people without a written scripture] and conversion to other religion has an impact on the parents and the community. [paraphrased].

On the contrary, some individual religious practitioners use derogatory words to describe the other, like the use of kafir or infidel for non-Muslims in northern Nigeria, which sometimes connotes the possibility of picking up a fight with non-Muslim residents. Also, some Christians, although refer to non-Christians as unbelievers (aláigbàgb) in southwest yet does not mean hate but an intent to pray for their conversion. Regardless, many who have both religions represented in their extended families within southwest Nigeria address one another as family regardless of religious affiliation. This unifies them for community peacefulness.

The strength of Maku's Muslim teaching is that Christians are not unbelievers (kafir) to be confronted or persecuted by Muslims. Like Maku's argument, a Senegalese Imam suggests, Christians are not kafir (Wisconsin-n.a., 2009). Maku's teaching appeals to tolerance and peacefulness among the Yorùbá within the context of the Yorùbá culture, while many Christians like Gideon seek to live in peace and holiness as suggested in the focus group one [FGD1] in this study. However, religious militant groups do not adhere to these fair religious interpretations, as gathered among the Spetrí residents, hence seek an alternative teaching more fundamentalist in nature.

Another factor identified as an indirect cause of violence is the slackness in house leaders or community meeting, where disputes are meant to be discussed and social events that unite are promoted. It was noted that the Spetrí community were peaceful when tolerant teachings and similar ideas were operational until less tolerant alternatives were brought in through a foreign trained local resident. Thus, a community with complimentary teachings appear more harmonious than the one with opposing alternatives. Similarly, in a community with two or more opposing operational norms, the one that dominates determines the general outlook of such a community. An understanding of one's neighbour's values, teachings, and interpretations of their religion also increases the community's ability to sustain their peacefulness. 
In the Senegalese context, both religious festivals are celebrated together by their communities that is made up of mixed families like the Yorùbá, although the percentage of Christians is lower, at around 5\% (Senegaln.a., 2009), compared to the equal split among the Yorùbá. Yorùbá Christians and Muslims also come together on social grounds. By inference, the common themes of Islam and Christianity are often encouraged to be discussed in dialogue meetings, rather than the areas of differences. In the Senegal for example:

For the Imam (the 83-year-old), 'Islam' means 'peace'. He pointed out that the Qur'an not only mentions but accepts many prophets in the Bible such as Moses, Abraham and Jesus. In his community, Muslim and Christian leaders often invite the other side to official events. For example, when the Cardinal came to Saint Louis for a visit recently, the Imam was invited and, because he was too frail to go, he sent a representative. The main challenges facing the Muslim community are poverty and the preservation of shrines such as mosques. (Wisconsin).

There was a poverty concern among the Senegalese (95\% Muslims and 5\% Christian). Such concerns are present among some Nigerians. The former Emir of Kano who was also the former governor of the Central Bank of Nigeria, Sanusi Lamido Sanusi, claims poverty as endemic among northern Nigerian Muslims (2017), whilst Nigeria has had more Muslim northern leaders as presidents and heads of state than any other religion's representation since its independence in 1960. The argument about poverty in northern Nigeria is logically indefensible and poverty as a form of economic violence in Nigeria requires a further research. A practising Christian Nigerian president, Goodluck Ebele Jonathan established and built many schools for the Almajiri northern Muslim children who ordinarily were not encouraged to attend a regular school by the northern cultural system (Njoku, 2020; Reliefweb, 2020). Yet the administration that took over from Jonathan, led by a practising Muslim, retired General Muhammadu Buhari did less to keep up his predecessor's pace. Mysterious mist covers the underdevelopment in northern Nigeria.

On a positive note, the southern Nigerian Muslims present the Christians as their kinsmen and vice versa, as seen in Maku's illustration and the three focus group meetings carried out in the region [FGD1, 2, 3]. Even as far back as 1800, Yorùbá Muslims have been delighted for their kinsman, Samuel Ajayi Crowther becoming a recognized Christian and a bishop of the Church of England, (Cole, 2004; Law, 1991; Milsome, 1987). Crowther was the first indigenous Christian bishop in West Africa. The virtues of love and understanding are paramount for the Yorùbá, as suggested in FGD1, FGD3, and further affirmed in the interview with Babatunde and İyab (both being university Christian students), and Alhaja (a Muslim lady in a local family house) in this study (FI). In another interview, Lateef [a younger Imam whose brother converted to Christianity and became a Christian minister], Maku (an older Imam), and Wolé (an Islamic scholar) in different towns and on different occasions present a similar view (FI). Religious interpretations and the culture being promoted have a lot to contribute to societal peacefulness. The views such interpreters and/or leaders held about religion have facilitated harmony when presented well to their community, which is a good heritage.

The peaceful relations among the Senegalese are like those among the Yorùbá. Kukah, a Roman Catholic bishop in northern Nigeria writing on the strength of the interaction between Christians and Muslims in Senegal, suggests, '[a]s history has shown us, any system that is not anchored on the realisation of the good of all is doomed to fail' (2007, p. 163). Hence, Senegal has come to attention in recent years among scholars of religion, anthropology and communication, due to the peaceful relations among the Senegalese Christians and Muslims. The specific attributes observed among the Senegalese are their culture of hospitality, referred to as teranga; mixed marriages; Muslim children being accepted in the Catholic school and thereby coming to understand the other's beliefs, and the adults' participation in both Christian and Muslim festivals (SenegalUW-Collaboration, 2009). Also, the Senegalese religious leaders engaged in dialogue at the community level and have mutual concern for one another. These are like what is obtainable among the Yorùbá as they use the idea of family relations, holding house and community leaders' meetings to unite and promoting social interaction to settle disputes. 
Research among the Senegalese is ongoing and open for contributions, asking questions such as:

What do you think of Senegal's model for interfaith peace? Is it a special case or can some parts of it be replicated in other countries? What else can be done to increase mutual understanding of Muslims and Christians? Senegal-Collaboration. (Collaboration)

In another section, they asked:

What role can religious leaders, Muslim or Christian, play in promoting interfaith harmony? Will Senegal's model work in your community? (Wisconsin).

These are relevant questions, like those in this study among the Yorùbá located in peace and conflict studies, relevant to dialogue, anthropology as well as communication studies. Yet, it is not simply a matter of replicating the Senegalese case but of discovering other communities that already exhibit such [inter-religious] harmony. This is not only to ascertain the means of increasing mutual understanding among religions but also to analyse what is currently being done to sustain the peace and manage their disputes. Similarly, leaders' roles are as important as the contents of the religious teachings and the interpretations they provide their followers along with the accepted cultural grounds for accommodating such to enhance their harmony. So, ongoing discourses about accommodating religious heritage contribute to the knowledge of peace in religious society.

\subsection{Intolerant Outside Influence on Peaceful Societies}

To further connect this discourse with peacefulness, the author finds the already established peaceful societies (PS) useful. Considering the peaceful societies' attitudes to strangers, he refers to the Paliyans, Semai, and Chewong as examples. There are various situations that mend the frequency and seriousness of disputes among the Paliyans, but often they maintain non-violence as they avoid external pressure or influence, and other possible causes of violence like alcoholism and a lack of respect (Gardner, 2000). The Semai had suffered enslavement in the hands of the Malays their neighbour as well as being kidnapped, raided, and killed. The Semai, thus teach their children to fear strangers through the teaching of terrifying stories of strangers' violence. Such early childhood training influences the later life of Semai people, (Dentan, 2001, pp. 89, 90). The Chewong also fear outsiders like the Malays and Chinese. Brave people with the potential to harm falls outside of the Chewong 'moral universe' (Howell, 1989, p. 53).

In support of the harmony among the Yorùbá is their ability to manage intolerant outside negative influence. The community's ability to handle various situations determines the outcomes on the individual cases. The Yorùbá are accommodating, and a stranger could be accommodated in a house and fed over the night free of charge in a local village, subject to the verification of their identity by the village heads and hunters. This hospitality has been abused by some strangers identified as non-Yorùbá bandit-herders who became thorns in the local's flesh as reported recently regarding kidnappings and leading of cattle to feed on the local's farms produce in Oke Ogun area of Oyo State, (BBC, 2021).

Still on outside influence through intolerant teaching strange to the locals; in a separate study by the author, the FGD2 participants in Spetrí expressed dismay at the interactions between the two religions that turned sour when a Yorùbá Muslim trainee (jelabí) returned to Spetrí from Cairo and spread antagonism and disunity among the people. They argue that jelabí taught some Muslim residents the art of violent jihad, encouraging attacks on Christians, teaching certain mode of dressing and burial rite. Some Muslims who became his followers became violent towards the Christian community. The Spetrí community could not bear the intolerance that followed, which led to violence, arson, arrests, and court cases. Gideon in the interview 
(FI) provides the names of those responsible for the spread of the conflicts between Christian and Muslim residents who have all died through natural causes (their names are withheld in this writing). He states:

In 1952, the Spetrí Improvement Union (SIU) was founded by the elites, without any Muslims then. [And] thirty years on, there has been harmony in Spetrí. You could hardly see any difference in the ways the traditionalists, Christians, and Muslims lived. [But] the Christians seemed to be more prosperous. Suddenly, some kids [young people] began to behave differently. [...] paraphrased).

One does not know the reason why Muslims were not involved in the improvement union, but it was claimed they all lived together in unity. Gideon further accused jelabí[1] of teaching Samex, who burnt down a Baptist Church in Shaki, a few miles from Spetrí. jelabí, according to Gideon, falsely accused some Christians of violence when Christians were exercising self-defence. However, jelabí was later caught in another violent act and arrested by the police. All these bother on the type of religious education jelabí received from outside of the community which did not support tolerance they were initially known for. The problem aggravated to breed 'hatred and individualism' according to Kúnlé. He adds:

'[...] After the death of the King, the town found it difficult to install a successor because the Christians were careful of accepting a Muslim king that will sanction intolerant form of Islamic over Spetrí town.'

Although the deceased king of Spetrí was a friendly Muslims, the negative image of Islam that jelabí represented put some Christians off as they no longer wanted a Muslim king as jelabí's intolerant activities continued to disturb their town's harmony. Thus, leadership and learned behaviour that prevails in a community has impact on the societal peacefulness.

Gideon further presented a concern about an inter-state underground (outside) plans to cause violence against the Yorùbá people, which he discovered in 2015:

17 May 2015. I was in a city guest house within the Republic of Benin. In the next (adjacent) room, the occupant, a Fulani who had taken his father for hospital treatment spoke to me. The man talked about Kaiama in Kwara State of Nigeria. He inquired about a man who built a big mansion in Spetrí whether he was a Christian or a Muslim. When he heard the man was a Christian, he warned that he (the Fulani young man) has been invited to KMS Islamic village near Iseyin (yo State) for a lecture. There, he met many people, including two people from Sptrí, training for a Boko Haram type of mission. Their focus was to burn down Spetrí and spare only Muslims.

Gideon informed his church, on his return to Nigeria about the above narration. The Deputy Governor of yo at that time was informed by an İgbòho indigene (name withheld) in other to secure the town and the entire Òkè Ògùn area of Oyo State. The need to safeguard the community from outside negative influence and violent activities alien to their community became an important long-term project if they would retain the peacefulness that they were previously known for. 


\subsection{Formal and Informal Theological Discourses}

Thus, theological discourse occurs in informal settings among the Yorùbá, usually unplanned but often well managed. The interpretation of concepts, actions, and cultural way of handling disputes and relating to one another are relevant bases for peacefulness. Most formal theological discourses among the Yorùbá take place in their communities, higher institutions of learning and as organized by Non-Governmental Organizations (NGOs). One example of an institutional dialogue was mentioned at FGD1a, where an Islamic Imam and a Roman Catholic priest addressed a university student community about tolerance and religious understanding. A student FGD1a participant, Ronke, said she was elated that the clerics expressed the commonalities of the two religions and highlighted the need for mutual understanding and love. Similarly, one of the notable NGOs that oversees Christian-Muslim dialogue in Africa is the Programme for ChristianMuslim Relations in Africa (PROCMURA), formerly known as the Islam in African Project. PROCMURA was formed by Christians to educate interfaith communities through dialogue. It often organizes programmes that include leaders and scholars from both religions, and sometimes engages in community awareness and developmental projects [see (PROCMURA-Witness, n.d.)]. PROCMURA lists its 'Christian and Muslim joint programmes of action' to include:

"Peace and peaceful co-existence between Christians and Muslims and ... [c]arrying out Christian mission and Muslim da'wah in a manner that respects the spirit of good neighbourliness' among others." (Witness).

PROCMURA present formal seminar fora with topics around the theological bases of peacefulness among Christians and Muslims. It has offices in western and northern Nigeria, while Ibadan (southwest Nigeria) was its headquarters until 1997 before it was moved to Nairobi, Kenya, (PROCMURA-Nigeria, n.d.). PROCMURA's operations in southwest Nigeria for many years could have contributed to the Yorùbá's peacefulness in one way or the other. Both formal and informal dialogues are common among the Yorùbá, which they often use to improve their understanding of one another's expectations to strengthen their unity.

The way theological discourses are managed have a lot to play a society's peacefulness. Kúnlé in the FGD2 argues that aggressive teaching and hatred expressed in some Christian sermons and Islamic da'wah (preaching), when not well handled can, and have caused disunity. Like Kúnlé (a Christian), Maku, a Muslim suggests Muslim da'wah should not be confrontational. Maku adds that insults and assault should not be condoned in the interaction between Christians and Muslims, and provocative statements about each other's religion should be avoided. These are the leaders' preventive measures and mediation in conflict situation among the Yorùbá.

By comparison, the PS's knowledge often informs the reasons for their carefulness or fears as they often leave the site of danger or strangers based on their previous experience. Sometimes, they assess the situation or ideas being introduced to them for its value contents and if it does not contradict their community values. Although the PS maintain their values and appear as closed groups unlike the Yorùbá who are more open to strangers and civilization, some PS appear to be selective in what they consider relevant to their wellbeing. Bonta reports that the Canadian Hutterites respond well to the coronal virus (covid-19) outbreak by restricting other colonies' access to their community to prevent cross infection as would in big cities in the Yorùbáland. The PS also stopped the eating together in their communal dining hall contrary to how they used to do before the outset of the global covid-19 pandemic. They now go out only for the essential commodities and use hand sanitizers, gloves, and masks to maintain a good prevention of the virus especially during the pick of the pandemic. Being Christians, they have reduced the number acceptable for each worship service to 15 and do that in turn to accommodate all the people in their colony, (Bonta, 2020). Likewise, many Yorùbá churches that met at some point during the pandemic also strategized to either rearrange the chairs in their worship halls or reduced the number allowed to sit on each pew to allow some forms of social distancing in addition to the use of masks and hands disinfectant during worship. Many Federal Government officials across the nation (the southwest Nigeria Yorùbá inclusive) were exempted from working during the 
covid-19 Pandemic, issued the 'Circular Compulsory Stay at Home' in March 2020, followed by a 'Partial Resumption' in April 2020 circular, while further say at home circulars were issued in March, and April 2021 (Dr Yemi-Esan, 2021). The only disheartening thing was many of the government officials in charge of the internationally provided palliative food supports hoarded the materials to be discovered by the masses during the second wave of the pandemic, (Awodipe, 2020; Eranga, 2020; Orjinmo, 2020). This is a potential slight on the government.

Considering informal interactions as a source of promoting peacefulness, the study among the Yorùbá in Ògbómoso suggests that family relationships and family bonds support dispute resolution. While the interaction at this level is mostly informal, it becomes formal when the family head or designated person is involved to settle the disputes. Akinjogbin's theory (1966) that the harmonious relationships among the Yorùbá based on their bi connections was partly evident in FGD1 until the FGD1a and FGD1c presented a deeper view that required a thick description of Muslims' theological festival meals. A closer attention at FGD1 reveals that disputes sometimes occur over the question of whether Christians should accept Muslims' festival meals. This requires thick description of the Yorùbá's peacefulness on religious grounds.

While some Christians eat such meals, some do not. Those who reject the meals support their claim by their belief that Jesus Christ's final atonement (see Hebrews Chapter 7 and 8) indicates no further requirement for a compulsory animal slaughtering in a regulated feast or sacrifice for worship purposes. They believe the Muslim festival constitutes a mandatory animal sacrifice. Discourses along this line are often informal while it becomes formal when the family head is involved to settle the conflict. Either way, the outcome is always peaceful, understanding each other better for the future possible engagements. Rich in the FGD1a, Fúnmiláy and Sàngó in FGD1c, all being Christians saw nothing wrong with eating a festival meal offered by Muslim friends or neighbours. Wùmí in FGD1a and Oyè in FGD1c reject the festival meal as it negates their Christian beliefs. To the latter, Jesus Christ's sacrificial death and resurrection presents the final atonement, but animal slaughtering for spiritual purposes (implied from the Muslim Eid Al-Adha festival) are no longer required or demanded by God. A similar discussion emerged in FGD3, when Wlé, a Muslim leader expressed his displeasure at non-Muslims (like Christians), throwing out such meals given to them. The participants at the FGD1 (Christians and Muslims) unanimously agreed that, when offered such festival meals, Christians who do not want to eat should be polite in declining the offer, rather than receiving and disposing it off.

Christians who want to eat would have made up their minds prior to the festival, as would those who do not want to eat. Some might change their minds either way through dialogue. In most cases, the Muslim celebrants will, over time and through years of interaction, identify the Christian neighbours who will partake in their feast and those who will decline. As examples, Wùmí, mb and Oyè will decline while Fúnmiláy and Sàngó will accept the offer. There are also instances of Muslims declining non-halal meals as it does not fall in line with the tenets of Islam. Yorùbá Christians do not knowingly offer such to their Muslim friends or neighbours as both religions get along through honest dialogue and tolerance either way.

Furthermore, the Inuit use radio communication to air complaint, educate their community, and express warmth for social interaction, but had a few traditional groups who prefer privacy rather than bringing concerns on the public radio, (Briggs, 2000, p. 122). As reserved as most PS appear to be, some are open to modern societies, although selective on what they consider beneficial without jeopardising their interest and peaceful valued life choices. The Yorùbá also find the use of radio useful in propagating their values through talks, music, jokes [àwàdà], drama and cinemas. In addition to social use of the radio, the Yorùbá have recently increased their use of the social media to educate one another about the happenings around them and to strengthen one another.

Nevertheless, most of the PS live in underdeveloped communities as the $\mathrm{Ju} /$ 'hoansi live in the desert, lacking medical facilities, with their life expectancy and fertility rates low, and child mortality high, (Biesele and Howell, 2015). A helping hand will be relevant yet, the PS's worldview must be examined with carefulness by non-indigenes. For instance, many of them lack electricity, but may not feel the lack as much as those in the modern societies would think they do because since some never had it, would not feel its absence so desperately as researchers might think they do. The Yorùbá on the other hand are much more civilized and 
open to industrialization if offered with the resources to reach their potentials.

\section{Unravelling the Yorùbá's Peacefulness}

A thick description about peacefulness in the face of intolerance reveals that many topics are being examined at various levels and problems being spotted and resolved among the Yorùbá. The level of religious provocation for instance, grew when some members of the community tacitly or willingly co-operated with the outside influence engineered by jelabí's strange teachings to become intolerant. The provocation by the intolerant group took root in the area due to a lack of proactive leadership to stop it. Without the insiders' co-operation, it would have been difficult for intolerance to blossom, which authenticates the Yorùbá saying, olè ilé ní nsi ilkùn fún tòde [literally translated as 'the thief in the house opens the door for the burglars']. Also implying that before the arrival of the strange intolerant teaching in the town, all the three religions, Islam, Christianity and the indigenous Yorùbá have lived together relatively peacefully.

One of the reasons for the fundamentalist/militants' rebellion can be attributed to their not being involved in development projects as could be inferred from Gideon's earlier quote, even when Gideon could not see this as important. However, the responsible way of rectifying the imbalance should not be jelabí's led violence. Nevertheless, the supposed leaked planned training to attack the unsuspecting Christians indigens of Spetrí in Oke Ogun area of Oyo State negates the act of mluabi well referred among the Yorùbá as their ethic of human relation.

So, Maku is known for his religious toleration and many Spetrí Christians speak well of him. This implies that not many Spetrí Muslims were violent towards Christians as the violent individuals are in the minority. The intensity of the intolerance and the responses of the responsible religious community determine the people's peacefulness. In addition to Maku's, the Sun of Ògbómosoland, Oba Jimoh Oladuni Ajagungbade (III), a Muslim king showed love and support for Christian and Muslim communities. In 2017, the Sun released the formerly leased land as a gift to the Nigerian Baptist Convention, the site of the Nigerian Baptist Theological Seminary, and the Bowen University Teaching Hospital Ògbómoso. This is a kind of gesture towards Christians by a Muslim leader in Yorùbáland is worth mentioning.

\section{Conclusion}

A violent fanatical individual or group can threaten the peace of a society. While a lack of development cannot be ruled out as a possible cause of aggression in human society, a negative outside influence along with the associated learned behaviours alien to a community are found to contribute to the community's disharmony. The ability to stop violence or disunity often helps to keep the peace, as Galtung $(1969,2000)$ seeks for positive peace and Bond (2014) describes peace as a continue process. Societal violence or insecurity, however, can lead to underdevelopment as the operators of some of the developmental projects like the fishpond in Sepeteri were forced to leave because of the violence and the project deteriorated with no competent committed hands to manage it.

The two religious' communities, Christians and Muslims can learn to strengthen their peaceful relations over time as positive common values are explored and promoted without necessarily compromising their beliefs or given to syncretism. In general, the Yorùbá are peaceful, striving to avoid religious conflict as they seek to treat each other as family (bi), affirming Akinjogbin's family theory (1996), which is one of their cherished

heritages. It is, however, unclear what the outcome will be as the harmonious Yorùbá communities try to handle any underground attempts of any outsiders or outlawed strangers to disrupt their peacefulness.

\section{References}

Akinade, A. E. (1996). Christian-Muslim Dialogue in Yorubaland: An Ecumencial (sic) Study (Ondo-Yoruba Nigeria, African people) Union Theological Seminary]. United States. 
Akinjogbin, I. A. (1966) 'The Oyo Empire in the 18th Century - A Reassessment', Journal of the Historical Society of Nigeria, 3(3), pp. 449-460.

Alhaja 2016. Interview at the Osalagbede Compound, Ogbomoso, Nigeria. In: Olayinka, A.S. Research Data.

Awodipe, T. (2020). Stakeholders Decry Women's Exclusion, HOarding of Palliatives. The Guardian Woman. https://guardian.ng/guardian-woman/stakeholders-decry-womens-exclusion-hoarding-of-palliatives/

Babatunde 2016. Interview at the Wildlife and Fisheries Department of the Osun State University, Ejigbo Campus. In: Olayinka, A.S. Research Data.

BBC. (2021). Sunday Igboho: the Nigeria Car Salesman going after Cattle Herders. https://www.bbc.co.uk/news/world-africa-55934275

Biesele, M. and Howell, N. (2015) "The Old People Give You Life": Aging Among !Kung Hunters-Gatherers. Available at: $<$ http://cas.uab.edu/peacefulsocieties/wp-content/uploads/sites/6/2015/11/BieHow81.pdf $>$.

Bond, C. J. (2014). Positive peace and sustainability in the mining context: beyond the triple bottom line. Journal of Cleaner Production, 84, 164-173. https://doi.org/https://doi.org/10.1016/j.jclepro.2014.01.033

Bonta, B. (2020) Canadian Hutterites Cope with COVID-19. Peaceful Societies: Alternatives to Violence and Wars: Department of Anthropology, University of Alabama, Birmingham. Available at: https://cas.uab.edu/peacefulsocieties/2020/04/16/canadian-hutterites-cope-with-covid-19/.

Briggs, J. L. (2000) 'Conflict Management in a Modern Inuit Community', in Peter P. Schweitzer, M.B.a.R.K.H. (ed.) Hunters and Gatherers in the Modern World: Conflict, Resistance, and SelfDetermination. Oxford: Berghahn Books, pp. 110 - 124.

Cole, G. R. (2004) 'Liberated Slaves and Islam in Nineteenth-Century West Africa', in Falola, T. and Childs, M.D. (eds.) The Yoruba Diaspora in the Atlantic World. Bloomington: Indiana University Press, pp. 383ff.

Dentan, R. K. (2001) 'Ambivalences in Child Training by the Semai of Peninsular Malaysia and Other Peoples', Crossroads: An Interdisciplinary Journal of Southeast Asian Studies, 15(1), pp. 89-129.

Dr Yemi-Esan, F. (7 April 2021). Circular (Office of the Head of Service of the Federation, Issue.

Eranga, I. O.-E. (2020). Covid-19 Pandemic in Nigeria: Palliative Measures and the Politics of Vulnerability. Journal of Maternal and Child Health and Aids, 9(2), 220-222. https://doi.org/10.21106/ijma.394

FGD1 (2016) Focus Group Discussion FGD1, Ogbomoso, Nigeria.

FGD2 (2016) Focus Group Discussion FGD2, Sepeteri, Nigeria.

FGD3 (2016) Focus Group Discussion FGD3, Ilorin, Nigeria.

Funmilayo (2016) Focus Group Discussion FGD1c, Ogbomoso, Nigeria.

Gabu 2016. Interview in Spetrí Town. In: Olayinka, A.S. Research Data.

Galtung, J. (1969). Violence, Peace, and Peace Research. Journal of Peace Research, 6(3), 167-191.

Galtung, J. (2000). Conflict Transformation by Peaceful Means (the Transcend Method) (Participants' Manual, Issue. https://www.transcend.org/pctrcluj2004/TRANSCEND_manual.pdf

Gardner, P. M. (2000) ' "Respect and Nonviolence among Recently Sedentary Paliyan Foragers." ', Journal of the Royal Anthropological Institute, 6, pp. 215-236.

Gideon 2016. Interview at Sepeteri, Oyo State. In: Olayinka, A.S. Research Data.

Howell, S. (1989) “ “'To Be Angry Is Not To Be Human, But To Be Fearful Is': Chewong Concepts of Human Nature".', in Willis, S.H.a.R. (ed.) Anthropological Perspectives. London: Routledge, pp. 45-59. 
Iyabo 2016. Interview at the Wildlife and Fisheries Campus. In: Olayinka, A.S. Research Data.

Department of the Osun State University, Ejigbo

Kukah, M. H. (2007) 'Christian-Muslim Relations in Sub-Sahara Africa: Problems and Prospects', Islam and Christian-Muslim Relations, 18(2), pp. 155-164.

Kúnlé (2016) FGD2 Focus Group Discussion two at Sepeteri.

Lateef 2016. Interview of an Imam who also had Western Education and a Christian brother. In: Olayinka, A.S. Research Data.

Law, R. (1991) The y empire, c.1600-c.1836: a West African imperialism in the era of the Atlantic slave trade. Modern revivals in history Y Aldershot: Aldershot: Gregg Revivals.

Maku, A. 2016. Interview of an Imam without the Western Education. In: Olayinka, A.S. Research Data.

Milsome, J. (1987) From Slave Boy to Bishop: The sStory of Samuel Adjayi Crowther. Cambridge: Lutterworth Press.

Nigerian Dialogue: [a journal of inter-faith studies on the relation between Christianity and non-Christian religions]. (1976). the University.

Njoku, G. (2020). Children Adjust to Life outside Nigeria's Almajiri System. UNICEF. Retrieved 08/04/2021. https://www. unicef .org/nigeria/stories/children-adjust-life-outside-nigeriasalmajiri-system>

Oludele, O. A. (2007). Solomon Aisa Ige, 1890-1982: Nigerian Baptist Convention, Nigeria.

Omobo 2016. Interview in Mixed/Interfaith Marriage Context. In: Olayinka, A.S. Research Data.

Orjinmo, N. (2020). Why Nigerian Looters are Targeting Covid-19 Aid. British Broadcasting Corporation (BBC) News. Retrieved 14/04/2021 from https://www.bbc.co.uk/news/world-africa-54695568

Oye (2016) Focus Group Discussion FGD1c, Ogbomoso, Nigeria. Research Data.

PROCMURA-Nigeria (n.d.) The PORCMURA Nigeria West Area. Nairobi: Procmura: https://www. procmura -prica.org/en/?p=1579 (Accessed: 29/10/2016 2016).

PROCMURA-Witness (n.d.) Faithful Christian Witness \& Christian Constructive Engagement with Muslims for Peace and Peaceful Co-existence. Nairobi: Procmura: https://procmura -prica.org/en/.

Reliefweb. (14 May 2020). The Almajiri Situation. UNHCR. Retrieved 08/04/2021 from https://reliefweb.int/report/nigeria/almajiri-situation

Rich (2016) A Participant at the Focus group Disscusion 1a in Ogbomoso.

Ronke (2016) Focus Group Discussion FGD1a, Ogbomoso, Nigeria.

Sango (2016) A Participant at the Focus group Disscusion 1c in Ogbomoso.

Sanusi, L. S. (2017) Union Bank of Nigeria: 'The Next 100: No Peace, No Prosperity'. Available at: https://www.youtube.com/watch?v=fOv86kWdOg4.

Senegal-n.a. (2009) Senegal: Conversation in a University', Regions and Themes: Africa. https://insideislam.wisc.edu/regions-and-themes/africa/senegal-conversation-in-a-university/, available at: https://insideislam.wisc.edu/regions-and-themes/africa/senegal-conversation-in-a-university/.

Senegal-UW-Collaboration (2009) 'Senegal: Model for Interfaith Peace', Regions and Themes: Africa. Inside Islam: Dialogue \& Debates. Challenging Misconceptions Illuminating Diversity. A Collaboration of the UWMadison's National Resource Centres and WPR's Here on Earth: Radio Without Borders.: University of Wisconsin-Madison. Available at: https://insideislam.wisc.edu/regions-and-themes/africa/ senegal -modelfor-interfaith-peace/. 
Wisconsin-n.a. (2009) Senegal: An Imam in Saint Louis', Regions and Themes:Africa: https://insideislam.wisc.edu/regions-and-themes/africa/ senegal -an-imam-in-saint-louis/, .

Wlé (2016) FGD3: The focus group discussion number 3 in Ilorin, Kwara State.

Wumi (2016) Focus Group Discussion FGD1a, Ogbomoso, Nigeria.

Note

[1] All the names used are either pseudo names or reworded in a way to keep the anonymity of the participants. 